\title{
Luaran Jangka Panjang Transplantasi Ginjal pada Anak
}

Eka Laksmi Hidayati

Departemen Ilmu Kesehatan Anak Fakultas Kedokteran Universitas Indonesia-RSUPN Cipto Mangunkusumo

\begin{abstract}
Abstrak
Transplantasi ginjal merupakan pilihan utama terapi pengganti ginjal pada pasien dengan penyakit ginjal kronik stadium 5 . Beberapa faktor pada periode pratransplantasi, perioperatif, dan pascatransplantasi ikut memengaruhi luaran jangka panjang pada pasien anak yang menjalani transplantasi ginjal. Faktor-faktor pratransplantasi yang memengaruhi, antara lain, etiologi dasar penyakit ginjal kronik, kondisi fisis sebelum transplantasi, status urodinamik, jenis donor, usia resipien, serta kesesuaian HLA antara resipien dan donor. Teknik pembedahan, kecukupan perfusi darah, dan cold ischemia time selama operasi berperan penting dalam keberhasilan transplantasi. Setelah menjalani prosedur transplantasi, penggunaan obat-obatan imunosupresan jangka panjang secara optimal merupakan kunci keberhasilan transplantasi. Pemantauan secara ketat terhadap kepatuhan terapi, reaksi penolakan organ, infeksi, keganasan, kelainan metabolik, dan gangguan kardiovaskular, dibutuhkan untuk memastikan keberhasilan transplantasi dan mendeteksi adanya komplikasi terkait prosedur transplantasi. Sari Pediatri 2022;23(5):346-52
\end{abstract}

Kata kunci: luaran jangka panjang, transplantasi ginjal, anak

\section{Long-term Outcome of Kidney Transplantation in Children}

Eka Laksmi Hidayati

\begin{abstract}
Kidney transplantation is the first choice of kidney replacement therapy in patients with chronic kidney disease stage 5. Several factors in the pre-transplant, perioperative, and post-transplant period contribute to the long-term outcome in children after kidney transplantation. Pre-transplantation factors include etiology of chronic kidney disease, physical condition before transplantation, urodynamic status, type of donor, age of recipient, and HLA compatibility between recipient and donor. Surgical techniques, the adequacy of blood perfusion, and cold ischemic time during surgery play an important role in the success of a transplant. After the transplant procedure, the optimal use of long-term immunosuppressant drugs is the main key to successful transplantation. Closed monitoring to the treatment compliance, organ rejections, infections, malignancies, metabolic abnormalities, and cardiovascular disfunction are needed to ensure the success of the transplantation procedure and detect any complications after transplantation procedure. Sari Pediatri 2022;23(5):346-52
\end{abstract}

Keywords: long-term outcome, kidney transplantation, children

Alamat korespondensi: Eka Laksmi Hidayati. Departemen Ilmu Kesehatan Anak Fakultas Kedokteran Universitas Indonesia-RSCM, Jakarta. Jl. Salemba Raya No. 6 , Jakarta Pusat 10430. Email: eka.laksmi@ui.ac.id 


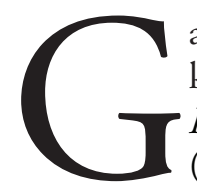

agal ginjal terminal atau penyakit ginjal kronik (PGK) stadium 5 menurut kriteria Kidney Disease: Improving Global Outcomes (KDIGO), merupakan penurunan fungsi ginjal dengan laju filtrasi ginjal kurang dari $15 \mathrm{ml} /$ menit $/ 1,73 \mathrm{~m}^{2} .{ }^{1}$ Anak dengan gagal ginjal terminal harus menjalani terapi pengganti ginjal, pilihannya adalah dialisis rutin jangka panjang atau transplantasi ginjal.

Hingga saat ini, transpantasi ginjal merupakan pilihan utama terapi pengganti ginjal yang dianggap terbaik dari sisi kualitas hidup pasien. Di Indonesia, transplantasi ginjal pada pasien anak pertama kali dilakukan di Rumah Sakit Dr. Cipto Mangunkusumo (RSCM) pada Maret 2013. Hingga Agustus 2018, telah dilakukan 11 kali transplantasi ginjal pada 10 anak di RSCM, seluruhnya merupakan donor hidup. ${ }^{2} \mathrm{Di}$ Amerika Serikat, telah dilakukan 12189 transplantasi ginjal pada 11.186 pasien anak sejak tahun 1987-2013 dan kini sekitar 700-800 tranplantasi ginjal pada anak dilakukan setiap tahun. Angka kesintasan pasien pada tahun ke-1, ke-5, dan ke-10 pascatransplantasi sebesar $98 \%, 95 \%$, dan $90 \%$, dan angka kesintasan ginjal donor tahun ke-1 dan ke-5 sebesar 94\% dan 83\% untuk donor hidup, serta $88 \%$ dan $71 \%$ untuk donor kadaver. ${ }^{3,4}$ Makalah ini akan membahas mengenai berbagai faktor yang memengaruhi luaran jangka panjang pada pasien anak yang menjalani transplantasi ginjal.

\section{Faktor yang Memengaruhi Fungsi Ginjal Donor}

\section{Pratransplantasi}

- Etiologi dasar gagal ginjal

Penyebab tersering gagal ginjal terminal pada anak adalah kelainan kongenital pada ginjal dan saluran kemih, terutama pada kelompok anak usia muda, dan focal segmental glomerulosclerosis (FSGS) pada kelompok anak usia remaja. ${ }^{3,5}$ Beberapa etiologi primer gagal ginjal terminal memiliki risiko kekambuhan pascatransplantasi yang relatif lebih tinggi dan meningkatkan risiko kegagalan organ donor di kemudian hari, seperti FSGS dengan risiko kekambuhan yang mencapai $50-80 \%$ dan menjadi salah satu penyebab kegagalan organ donor atau sindrom hemolitik uremik atipikal yang memiliki risiko kekambuhan 50-80\% dengan risiko kegagalan organ donor sebesar $90 \%$ pada kasus rekuren. ${ }^{5}$

- Indikasi dan waktu transplantasi ginjal Persiapan terapi pengganti ginjal, termasuk transplantasi, sebaiknya mulai dilakukan pada saat penurunan fungsi ginjal mencapai kurang dari 30 $\mathrm{ml} / \mathrm{menit} / 1,73 \mathrm{~m}^{2}$ atau anak berada pada penyakit ginjal kronik (PGK) stadium 4. ${ }^{5}$ Transplantasi ginjal dianggap sebagai pilihan terapi pengganti ginjal terbaik pada gagal ginjal terminal, baik ditinjau dari aspek kesintasan maupun kualitas hidup pasien., 3,6,7 Dialisis umumnya diperlukan sebelum dilakukan transplantasi untuk menstabilkan keadaan pasien selama menunggu tersedianya donor yang sesuai. Beberapa institusi baru melakukan transplantasi saat berat badan anak lebih dari $10 \mathrm{~kg}$ untuk meningkatkan peluang kesintasan. ${ }^{8,9}$ Menurut The Pediatric Committee of The American Society of Transplant Physicians, beberapa indikasi transplantasi ginjal, antara lain, gejala uremia yang tidak respon terhadap terapi standar, gagal tumbuh karena pembatasan asupan kalori, keterlambatan perkembangan psikomotorik, hipervolemia, hiperkalemia, dan penyakit tulang metabolik akibat osteodistrofi ginjal. ${ }^{9}$

Transplantasi ginjal dapat menjadi modalitas awal terapi gagal ginjal terminal pada anak tanpa didahului dialisis terlebih dahulu (preemptive transplantation). Menurut data North American Pediatric Renal Trials and Collaborate Studies (NAPRTCS), sebanyak 25\% dari total transplantasi primer merupakan preemptive transplantation. ${ }^{3,5}$ Data dari NAPRTCS dan United States Renal Data System (USRDS) menunjukkan luaran kesintasan dan tingkat penolakan organ donor yang lebih baik pada preemptive transplantation dibandingkan penerima transplantasi yang telah menjalani dialisis. ${ }^{3,5,10,11}$ Terdapat beberapa hal yang membuat preemptive transplantation tidak dapat dilakukan, yaitu pada kasus sebagai berikut: dibutuhkannya nefrektomi pratransplantasi, gagal ginjal terminal karena autoimun dengan titer autoantibodi yang masih tinggi atau karena penyakit yang masih aktif dan progresif, seperti pada hemolytic uremic syndrome, infeksi aktif, atau belum siapnya pasien dan keluarga menjalani prosedur terapi pascatransplantasi. ${ }^{5}$

- Faktor urologi

Evaluasi saluran kemih bagian bawah harus dilakukan 
sebelum transplantasi untuk memastikan bahwa pasien tidak ada kelainan dalam proses berkemih. Pemeriksaan meliputi voiding cystourethrogram dan uji urodinamik. Pasien dengan refluks vesikoureter tingkat lanjut atau ISK yang menetap harus menjalani nefroureterektomi untuk mengurangi risiko sepsis akibat ISK.,9

- Jenis dan usia donor

Sejumlah studi menunjukkan luaran yang lebih baik pada transplantasi yang berasal dari ginjal donor hidup. ${ }^{3,5}$ Data NAPRTCS tahun 2014 menunjukkan kesintasan organ donor setelah 5 tahun sebesar $83 \%$ pada donor hidup dan $71 \%$ pada donor kadaver. ${ }^{3,5}$

Angka kesintasan organ donor ditemukan lebih rendah pada organ dari donor kadaver yang berusia kurang dari dua tahun atau lebih dari lima puluh tahun, tetapi tidak ditemukan perbedaan angka kesintasan terkait usia donor hidup.,

- Usia resipien

Data NAPRTCS tahun 2014 menunjukkan luaran kesintasan organ donor dalam lima tahun lebih rendah pada anak berusia $<1$ tahun dan $>12$ tahun pada penerima donor kadaver (63\% dan 68\%) dibandingkan pada kelompok usia 1-5 tahun (75\%) dan 6-12 tahun (73\%). Pada donor hidup, angka kesintasan organ donor paling rendah pada kelompok usia $>12$ tahun (79\%) dibandingkan kelompok usia $<1$ tahun (84\%), 2-5 tahun (86\%), dan 6-12 tahun (79\%). ${ }^{3}$

- Sensitisasi dan kesesuaian HLA

Kesesuaian HLA yang identik akan memberikan luaran kesintasan organ donor terbaik. Pada keadaan tertentu mengoptimalkan kesesuaian HLA tidak selalu bermanfaat, terutama pada pasien yang menunggu donor kadaver. Pembatasan pemberian donor hanya bila kesesuaian HLA sangat tinggi akan meningkatkan waktu tunggu yang secara tidak langsung akan meningkatkan morbiditas akibat gagal ginjal dan dialisis. ${ }^{12}$

Bila pratransplantasi didapatkan anti-HLA antibodies (sensitisasi), maka akan meningkatkan risiko terjadinya reaksi penolakan yang dimediasi antibodi dan kegagalan organ donor lebih awal. Sensitisasi dapat terjadi karena transfusi, kehamilan, dan transplantasi sebelumnya. Dengan demikian, penting dilakukan pemeriksaan untuk menilai adanya sensitisasi pada resipien terhadap antigen HLA donor serta kesesuaian (crossmatch) anti-HLA terhadap antigen dari donor yang spesifik., 512

\section{Perioperatif}

Perkembangan teknik pembedahan serta pemahaman yang lebih baik mengenai kelainan urologi, manajemen volume perioperatif, dan pemilihan donor telah meningkatkan luaran pembedahan pada transplantasi ginjal. Salah satu faktor penting adalah resusitasi intraoperasi yang agresif guna menjaga aliran darah aorta dan status volume sehingga dapat mempertahankan perfusi yang adekuat ke organ donor. ${ }^{9,12,13}$ Selain itu, cold ischemic time lebih dari 24 jam berkaitan dengan risiko delayed graft function (DGF) yang lebih tinggi. ${ }^{12}$ Studi lain menunjukkan cold ischemic time lebih dari 12 jam pun meningkatkan risiko DGF dengan $\mathrm{OR}=5,26$ (IK $95 \%$ 2,62-11,31). ${ }^{13}$

\section{Pascatransplantasi}

- Disfungsi ginjal donor

Disfungsi pada organ donor dapat terjadi segera hingga beberapa tahun pascatransplantasi. Delayed allograft function, merupakan kondisi oliguria hingga dibutuhkannya dialisis selama minggu pertama pascatransplantasi ginjal, yang berkaitan dengan luaran lebih buruk. ${ }^{12,14}$

Gangguan fungsi organ donor yang terjadi dalam 1 minggu hingga beberapa bulan pascatransplantasi seringkali disebabkan oleh penolakan akut, intoksikasi obat jenis penghambat kalsineurin, obstruksi saluran kemih, infeksi, hipovolemia, dan kekambuhan penyakit primer. Setelah 12 minggu pascatransplantasi, gangguan fungsi dapat pula disebabkan oleh pyelonefritis, sedangkan penurunan fungsi ginjal yang progresif dan terjadi dalam beberapa tahun pascatransplantasi umumnya disebabkan penolakan kronik, nefrotoksisitas akibat penghambat kalsineurin, nefrosklerosis akibat hipertensi, infeksi virus, serta kekambuhan penyakit primer. $^{14}$

- Reaksi penolakan ginjal donor

Penolakan ginjal donor hiperakut terjadi dalam beberapa menit pascatransplantasi karena aktivitas sistem imun yang diinisiasi oleh anti-HLA resipien yang sudah ada saat transplantasi, berikatan ke sel endotel pada ginjal donor. Penolakan akut merupakan penurunan fungsi organ donor secara 
cepat yang ditandai dengan peningkatan kreatinin serum. Tanda khas penolakan akut, seperti demam dan nyeri pada daerah organ donor sering tidak muncul karena pemberian imunosupresi sehingga reaksi penolakan akut hanya dapat dideteksi dari peningkatan kreatinin serum. Oleh karena itu, perlu dilakukan pemeriksaan kreatinin pascatransplantasi secara berkala untuk memantau keberhasilan transplantasi dan deteksi penolakan organ. ${ }^{14}$

Penolakan kronik merupakan penurunan fungsi ginjal donor secara perlahan yang ditandai dengan peningkatan serum kreatinin secara bertahap, peningkatan proteinuria, dan perburukan hipertensi, serta terjadi setidaknya tiga bulan pascatransplantasi. Faktor risiko penolakan kronik, antara lain, riwayat episode penolakan akut dan penggunaan siklosporin dosis rendah. ${ }^{14}$

- Terapi imunosupresi

Salah satu komponen penting dalam manajemen pascatransplantasi ginjal adalah obat imunosupresan yang berfungsi sebagai pengontrol respon imun untuk mencegah penolakan organ. Pemberian imunosupresan secara konvensional dibagi menjadi tiga fase, yaitu induksi, rumatan, dan untuk mengatasi penolakan akut. ${ }^{15,16}$

Terapi induksi merupakan pemberian imunosupresan secara intensif selama periode perioperatif untuk mencegah penolakan akut, setidaknya selama tiga bulan pascatransplantasi yang merupakan periode dengan risiko penolakan akut tertinggi, kemudian diturunkan bertahap hingga mencapai dosis rumatan dalam 6-12 bulan pascatransplantasi. ${ }^{15,16}$ Pilihan regimen yang digunakan dalam terapi induksi adalah antibodi poliklonal seperti anti-thymocyte globulin (ATGAM) atau rATG-thymoglobulin; antibodi monoklonal seperti alemtuzumab; antibodi terhadap reseptor IL-2 seperti basiliximab; atau agen nonbiologis (kortikosteroid, penghambat kalsineurin, dan antimetabolit) yang diberikan dengan dosis lebih tinggi dari dosis rumatan. ${ }^{15}$

Terapi rumatan merupakan pemberian imunosupresan jangka panjang untuk mencegah penolakan kronik. Pada fase ini, dosis imunosupresan diturunkan bertahap hingga dosis optimal terendah untuk mengurangi risiko efek samping, seperti infeksi atau keganasan. Pemberian kombinasi imunosupresan harus memperhatikan keseimbangan antara efek imunosupresi untuk mencegah chronic antibody-mediated rejection dengan efek samping yang minimal. Umumnya, pada terapi rumatan digunakan kombinasi tiga jenis imunosupresan, yaitu penghambat kalsineurin (takrolimus atau CsA), antimetabolit (MMF atau azatioprin), dan kortikosteroid (prednison atau metilprednisolon). ${ }^{6,15}$ The mammalian target of rapamycin (mTOR) inhibitor seperti everolimus dan sirolimus juga menjadi pilihan imunosupresan untuk rumatan, umumnya sebagai pengganti penghambat kalsineurin atau antimetabolit. ${ }^{15}$ Saat ini sedang diteliti terapi rumatan dengan dosis steroid sangat rendah hingga tanpa steroid sama sekali, tetapi belum dapat diambil kesimpulan karena hasil berbagai penelitian yang heterogen..$^{15,17-21}$

Tidak adanya pedoman mengenai imunosupresi pascatransplantasi ginjal pada anak menyebabkan perbedaan pemilihan imunosupresan antarinstitusi. Selain profil efek samping obat, beberapa institusi mempertimbangkan pemberian imunosupresan lebih intensif pada pasien yang lebih berisiko mengalami penolakan jaringan. Faktor-faktor yang memengaruhi pemilihan imunosupresan adalah faktor imunologis, seperti sensitisasi pasien, transplantasi pertama atau transplantasi ulang, riwayat episode penolakan akut sebelumnya, tingkat kecocokan HLA, risiko kekambuhan penyakit, dan inkompatibilitas $\mathrm{ABO} .{ }^{15}$ Faktor lain yang dapat menjadi pertimbangan pemilihan imunosupresan adalah keadaan klinis spesifik pada pasien seperti usia, obesitas, ras, hiperlipidemia, dan keterlambatan fungsi graft. $^{17}$

- Infeksi

Infeksi merupakan salah satu efek utama pemberian imunosupresi dan dapat memengaruhi kesintasan organ donor. Pasien pascatransplantasi seringkali mengalami infeksi virus umum seperti influenza atau adenovirus dengan manifestasi yang lebih berat. Infeksi varisela pada pasien pascatransplantasi dapat menyebabkan ensefalitis, pneumonitis, gangguan fungsi hati, hingga kematian. Oleh karena itu, pasien dianjurkan melengkapi vaksinasi rutin sebelum transplantasi dan pemberian imunosupresan. ${ }^{5}$

Infeksi saluran kemih merupakan infeksi tersering pada pasien pascatransplantasi dengan angka kejadian 15-33\%.6,14 Sebagian pasien dengan ISK berulang diberikan antibiotik profilaksis, tetapi harus pula dipertimbangkan manfaat dan risiko resistensi antibiotik akibat penggunaan antibiotik 
jangka panjang. ${ }^{6,17}$

Pasien transplantasi juga berisiko mengalami infeksi virus laten, seperti cytomegalovirus (CMV), Epstein-Barr virus (EBV), dan BK polyxoma virus $(\mathrm{BKV})$. Infeksi CMV dapat berupa infeksi primer dari donor seropositif kepada resipien seronegatif, atau reaktivasi dari donor pada resipien seropositif. Infeksi dapat bermanifestasi sebagai demam, pneumonitis, hepatitis, dan disfungsi organ donor. Pemeriksaan berkala dan pemberian profilaksis dengan gansiklovir atau valgansiklovir cukup efektif mengurangi morbiditas akibat infeksi CMV ${ }^{6,14}$

Infeksi EBV umumnya terjadi pada resipien seronegatif yang mendapat donor dengan serologi positif. Hingga saat ini belum ada profilaksis untuk infeksi EBV. Pada kasus infeksi EBV, dianjurkan untuk mengurangi pemberian imunosupresi serta pada sebagian pasien mungkin diperlukan terapi dengan rituksimab. ${ }^{14}$ Infeksi BKV dapat menyebabkan nefropati yang meningkatkan risiko kegagalan organ donor, terutama bila pasien sudah mendapat pengurangan imunosupresan dan pemberian antivirus. ${ }^{6,14}$

- Keganasan

Imunosupresi jangka panjang tidak hanya meningkatkan risiko infeksi, tetapi juga keganasan. Infeksi EBV pada pasien yang mendapat terapi imunosupresi berkaitan dengan peningkatan risiko post-transplant lymphoproliferative disease (PTLD). Data NAPRTCS 2014 menunjukkan insiden keganasan pascatransplantasi sebesar 2,6\%. Sebanyak 262 dari 310 keganasan yang terkonfirmasi merupakan PTLD dan sisanya merupakan nonPTLD. ${ }^{3}$ Median waktu dari transplantasi ke diagnosis keganasan adalah 14,9 dan 33 bulan untuk PTLD dan non-PTLD. ${ }^{3}$ Temuan tersebut berbeda dengan studi di Australia dan Selandia Baru yang menunjukkan insiden keganasan mencapai 16,7\% (289 dari 1734). Keganasan kulit nonmelanoma terjadi pada 196 kasus. Keganasan lain adalah PTLD, keganasan serviks, dan melanoma yang memiliki insiden tertinggi. ${ }^{22}$ Pencegahan keganasan pascatransplantasi antara lain dengan mencegah imunosupresi berlebih serta mengurangi pemberian imunosupresan pada pasien yang telah mengalami keganasan.

- Pertumbuhan dan perkembangan Sebagian besar anak mengalami perbaikan pertumbuhan pascatransplantasi ginjal, tetapi terdapat beberapa faktor utama yang dianggap memengaruhi tumbuh-kejar pascatransplantasi adalah usia saat transplantasi (prapubertas atau pubertas), fungsi ginjal donor, penggunaan kortikosteroid, dan pemberian terapi hormon pertumbuhan/recombinant human growth hormone (rhGH) ${ }^{6,9,12}$ Tumbuh-kejar yang optimal umumnya hanya terjadi pada kelompok pasien berusia $<5$ tahun. Pemberian steroid jangka panjang dan rutin setiap hari turut menjadi faktor pertambahan pertumbuhan pascatransplantasi tidak optimal. Gangguan pertumbuhan terjadi pada dosis kortikosteroid $>5 \mathrm{mg} / \mathrm{m}^{2} .{ }^{12}$

Pemberian rhGH pada pasien anak pascatransplantasi menunjukkan hasil yang cukup efektif untuk meningkatkan laju pertumbuhan pascatransplantasi, dan direkomendasikan untuk diberikan bila setelah satu tahun tidak terjadi tumbuh-kejar pada anak yang memiliki potensi tumbuh, dengan tinggi badan menurut usia dan jenis kelamin di bawah persentil 3, dan laju pertambahan tinggi badan kurang dari persentil 25. Sementara faktor risiko hambatan pertumbuhan lainnya sudah ditangani secara adekuat. ${ }^{12,23}$

Umumnya, pasien pascatransplantasi mencapai pubertas normal meski sebagian mengalami keterlambatan, terutama pada laki-laki., ${ }^{6,12}$ Pasien pascatransplantasi juga berisiko mengalami hambatan perkembangan psikososial. Salah satu faktor risiko adalah stres psikososial yang dihadapi terkait penyakit yang mereka alami. ${ }^{6}$

Periode remaja merupakan periode transisi anak menjadi dewasa dan periode pencarian identitas diri. Remaja mungkin lebih sulit menerima efek samping kosmetik dari pemberian imunosupresan. Pada fase ini terjadi peningkatan angka ketidakpatuhan, episode penolakan akut, serta kegagalan jaringan bila dibandingkan dengan kelompok usia lainnya., ${ }^{2,6}$

- Kepatuhan terapi

Terapi pascatransplantasi yang diberikan jangka panjang membuat kepatuhan turut menjadi kunci keberhasilan dalam mengoptimalkan kesintasan pasien dan organ donor Suatu kajian sistematis menunjukkan kepatuhan yang rendah pada kelompok usia remaja, yang mungkin dipengaruhi pula oleh efek kosmetik imunosupresan seperti kortikosteroid dan siklosporin. ${ }^{6,15,24}$ Angka ketidakpatuhan berobat lebih tinggi pada remaja, 
sedangkan angka kesintasan graft jangka panjang terendah pada kelompok anak adalah di usia remaja (12-14 tahun). ${ }^{25,26}$

- Kelainan metabolik

Risiko mengalami kelainan metabolik seperti obesitas, gangguan metabolisme glukosa, dislipidemia, dan anemia meningkat pada anak pascatransplantasi ginjal, sebagai akibat dari penggunaan imunosupresan. Insiden sindrom metabolik dilaporkan mencapai $25-68 \%$ dalam 1-2 tahun pascatransplantasi. Insiden berat badan berlebih dalam satu tahun pertama sekitar 20-30\%. Gangguan metabolisme glukosa yang berkembang menjadi post-transplant diabetes mellitus (PTDM) dilaporkan terjadi pada 3-20\% pasien. Faktor risiko gangguan metabolisme glukosa adalah penggunaan takrolimus, hiperglikemia peritransplantasi, dan riwayat keluarga penderita DM tipe II. Sementara itu, insiden dislipidemia pascatransplantasi mencapai 50\%, terutama dalam 6 bulan pertama. Faktor risiko utama dislipidemia pascatransplantasi adalah pemberian siklosporin, pemberian steroid dosis tinggi, hiperkolestrolemia pratransplantasi, dan resipien usia lebih muda. ${ }^{8}$

- Hipertensi dan gangguan kardiovaskular

Hipertensi merupakan salah satu komplikasi yang umum terjadi pascatransplantasi ginjal, yaitu sebesar $80 \%$ pada penerima donor kadaver dan $60 \%$ pada penerima donor hidup. Kejadian hipertensi pascatransplantasi dapat meningkatkan risiko penolakan kronik, menurunkan kesintasan organ donor, dan meningkatkan risiko komplikasi lain. Pada awal periode pascatransplantasi, hipertensi dapat disebabkan overload cairan, penolakan akut, atau efek samping imunosupresan. Setelah fase tersebut, hipertensi dapat disebabkan oleh efek imunosupresan, stenosis arteri renalis, hipoperfusi ginjal resipien, kekambuhan penyakit primer, dan obstruksi saluran kemih. Pemberian antihipertensi dapat dilakukan setelah mempertimbangkan etiologi hipertensi tersebut. Penggunaan penghambat ACE atau reseptor angiotensin harus hati-hati, terutama bila dicurigai adanya stenosis arteri renalis. Komplikasi seperti hipertensi, dislipidemia, diabetes mellitus, hiperhomosisteinemia, dan obesitas, yang juga dipengaruhi pemberian imunosupresan, akan meningkatkan risiko penyakit kardiovaskular. ${ }^{5}$

\section{Kesimpulan}

Transplantasi ginjal hingga kini merupakan modalitas terapi gagal ginjal terminal pada anak yang terbaik. Terdapat berbagai faktor yang memengaruhi angka kesintasan pasien dan organ donor pascatransplantasi ginjal pada pasien anak, yang meliputi faktor praoperatif, perioperatif, dan pascaoperatif. Meskipun perkembangan keilmuan dan teknologi terus meningkatkan angka kesintasan pasien dan kesintasan organ donor, masih diperlukan pengembangan dan penelitian lebih lanjut guna mencapai kesintasan dan kualitas hidup pascatransplantasi yang semakin baik.

\section{Daftar pustaka}

1. Kidney Disease: Improving global outcomes. KDIGO 2012 Clinical practice guideline for the evaluation and management of chronic kidney disease. Kidney Int Suppl 2013;3:136.

2. Pardede SO, Hidayati EL, Ambarsari CG, Puspitasari HA, Trihono PP, Tambunan T. Pengalaman transplantasi ginjal pada anak di Jakarta. Sari Pediatri 2019;21: 44-9.

3. North American Pediatric Renal Trials and Collaborative Studies. NAPRTCS 2014 Annual transplant report [Internet]. 2014 [disitasi pada 29 September 2019]. Didapat dari: https:// web.emmes.com/study/ped/annlrept/annualrept2014.pdf.

4. Hart A, Smith JM, Skeans MA, dkk. OPTN/SRTR 2016 Annual data report: kidney. Am J Transplant 2018;18:18-113.

5. McDonald RA. General principles of renal transplantation in children [Internet]. Niaudet P, Kim MS. (penyunting) UpToDate. 2019 [disitasi pada 27 September 2019]. Didapat dari: https://www.uptodate.com.

6. McDonald SP, Craig JC, Australian and New Zealand Paediatric Nephrology Association. Long-term survival of children with end-stage renal disease. $\mathrm{N}$ Engl J Med 2004;350:2654-62.

7. Holmberg C, Jalanko H. Long-term effects of paediatric kidney transplantation. Nat Rev Nephrol 2016;12:301-11.

8. Winterberg PD, Garro R. Long-term outcomes of kidney transplantation in children. Pediatr Clin North Am 2019;66:269-80.

9. Hebert SA, Swinford RD, Hall DR, Au JK, Bynon JS. Special considerations in pediatric kidney transplantation. Adv Chronic Kidney Dis 2017;24:398-404.

10. Amaral S, Sayed BA, Kutner N, Patzer RE. Preemptive kidney transplantation is associated with survival benefits among pediatric patients with end-stage renal disease. Kidney Int 2016;90:1100-8.

11. Vats AN, Donaldson L, Fine RN, Chavers BM. Pretransplant dialysis status and outcome of renal transplantation in North American children: a NAPRTCS Study. North American 
Pediatric Renal Transplant Cooperative Study. Transplantation 2000;69:1414-9.

12. McDonald RA. Outcomes of renal transplantation in children [Internet]. Niaudet P, Kim MS. (penyunting) UpToDate. 2019 [disitasi pada 27 September 2019]. Didapat dari: https://www. uptodate.com.

13. deFreitas MHB, Lima LC, Couceiro TC, daSilva WB, deFreitas MHB. Perioperative factors associated with delayed graft function in renal transplant patients. J Bras Nefrol 2018;40:360-5.

14. McDonald RA. Complications of renal transplantation in children [Internet]. Niaudet P, Kim MS. (penyunting) UpToDate. 2019 [disitasi pada 27 September 2019]. Didapat dari: https://www.uptodate.com

15. McDonald RA. Immunosuppression in renal transplantation in children [Internet]. Niaudet P, Kim MS, penyunting, UpToDate. 2019 [disitasi pada 27 September 2019]. Didapat dari: https://www.uptodate.com.

16. Tönshoff B, Melk A, Höcker B. Immunosuppression in pediatric kidney transplantation. Dalam: Geary D, Schaefer F, penyunting. Pediatric Kidney Disease. Berlin: Springer; 2016.h.1767-801.

17. Höcker B, Weber LT, Feneberg R, dkk. Prospective, randomized trial on late steroid withdrawal in pediatric renal transplant recipients under cyclosporine microemulsion and mycophenolate mofetil. Transplantation 2009;87:934-41.

18. Höcker B, Weber L, Feneberg R, dkk. Improved growth and cardiovascular risk after late steroid withdrawal: 2-year results of a prospective, randomized trial in paediatric renal transplantation. Nephrol Dial Transplant 2010;25:617-24.
19. Grenda R, Watson A, Trompeter R, dkk. A randomized trial to assess the impact of early steroid withdrawal on growth in pediatric renal transplantation: the TWIST study. Am J Transplant 2010;10:828-36.

20. Webb N, Douglas S, Rajai A, dkk. Corticosteroid-free kidney transplantation improves growth: two-year follow-up of the TWIST randomised controlled trial. Transplantation 2015;99:1178-85.

21. Sarwal MM, Ettenger RB, Dharnidharka V, dkk. Complete corticosteroid avoidance is effective and safe in children with renal transplants: a multicentre randomized trial with three-year follow-up. Am J Transplant 2012;12: 2719-29.

22. Francis A, Johnson DW, Craig JC, Wong G. Incidence and predictors of cancer following kidney transplantation in childhood. Am J Transplant 2017;17:2650-8.

23. Drube J, Wan M, Bonthuis M, dkk. Clinical practice recommendations for growth hormone treatment in children with chronic kidney disease. Nat Rev Nephrol 2019;15:57789.

24. Tönshoff B, Ettenger R, Strologo LD, dkk. Early conversion of pediatric kidney transplant patients to everolimus with reduced tacrolimus and steroid elimination: Results of a randomized trial. Am J Transplant 2019;19:811--22.

25. Dharnidharka VR, Fiorina P, Harmon WE. Kidney transplantation in children. N Engl J Med 2014;371:549-58.

26. Dobbels F, Ruppar T, De Geest S, Decorte A, Van DammeLombaerts R, Fine RN. Adherence to the immunosuppressive regimen in pediatric kidney transplant recipients: a systematic review. Pediatr Transplant 2010;14:603-13. 